\title{
Artificial insemination system without estrous observation in suckled beef cows
}

\author{
Sistema de inseminação artificial sem observação de estros em vacas de corte durante \\ período de amamentação
}

\begin{abstract}
Luiz Felipe Kruel Borges ${ }^{\mathrm{I}}$ Rogério Ferreira $^{\mathrm{I}}$ Lucas Carvalho Siqueira $^{\mathrm{I}}$ Rodrigo Camponogara Bohrer ${ }^{\mathrm{I}}$ Jacson William Borstmann ${ }^{\mathrm{I}}$ João Francisco Coelho de Oliveira ${ }^{\mathrm{I}}$ Paulo Bayard Dias Gonçalves ${ }^{\mathrm{I} *}$
\end{abstract}

\begin{abstract}
The aim was to develop a timed artificial insemination (TAI) system in suckled beef cows. Cows ( $n=227)$, 60-80 days postpartum, received estradiol benzoate (5mg) and a vaginal device containing $250 \mu \mathrm{g}$ of medroxyprogesterone

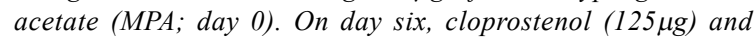
eCG (400IU) were administrated and calves were weaned for $88 \mathrm{~h}$. The devices were removed on day seven (BioRep group) or on day eight (TAI group). All cows of TAI group and cows of BioRep group that did not exhibit standing estrus received

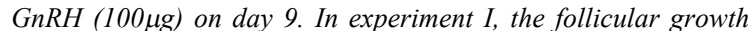
was monitored daily by transrectal ultrasound exams, from day 6 to day 9. The average size of the dominant follicle on day nine was $11.1 \pm 0.99 \mathrm{~mm}$ (BioRep, $n=7$ ) and $11.5 \pm 0.65 \mathrm{~mm}$ (TAI, $n=7)$ and all animals ovulated. In experiment II, the BioRep group cows $(n=106)$ were observed for estrous behavior after withdrawal of the device, twice a day for 48h, and inseminated $12 \mathrm{~h}$ after detection. In the TAI group $(n=107)$, the devices were withdrawn on day eight and after $24 \mathrm{~h}$ these cows and those from the BioRep group, which were not stand in estrus, received $100 \mu \mathrm{g}$ of GnRH and TAI $16 \mathrm{~h}$ later. The pregnancy rates were $57.6 \%$ (BioRep) and 52.3\% (TAI). In conclusion, an increase on MPA exposure time did not affect the follicular dynamics and pregnancy rates and allow TAI without estrous observation. Furthermore, the treatment for eight days provides an efficient TAI system in suckled beef cows.
\end{abstract}

Key words: beef cows, postpartum, TAI, MPA, ovulation.

\section{RESUMO}

O objetivo deste estudo foi desenvolver um protocolo de inseminação artificial com tempo fixo (IATF) em vacas de corte durante periodo de amamentação, avaliando o intervalo entre a retirada do progestágeno e a aplicação de GnRH sobre a dinâmica folicular e a prenhez. Para tanto, vacas ( $n=227)$ em pós-parto de 60 a 80 dias receberam benzoato de estradiol (5mg) e um pessário vaginal de acetato de medroxiprogesterona (250mg MAP; dia 0). No dia seis, os animais receberam cloprostenol sódico $(125 \mu \mathrm{g})$, gonadotrofina coriônica eqüina (400UI) e desmame temporário (88h). O $M A P$ foi retirado no dia sete (Grupo BioRep) ou no dia oito (Grupo IATF). Todas as vacas do grupo TAI e aquelas que não

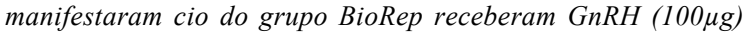
no dia nove. No experimento I, o monitoramento das estruturas ovarianas de 14 vacas foi realizado a cada $24 \mathrm{~h}$, desde o dia seis até 36 h após a aplicação de GnRH em ambos os grupos. $O$ tamanho médio do foliculo dominante no dia nove foi de

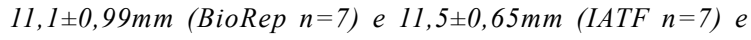
todos os animais ovularam. No experimento II, no grupo BioRep $(n=106)$, após a retirada do MAP, as fêmeas foram inseminadas com detecção de estro durante 48 horas. $O$ restante dos animais do grupo BioRep e todos do grupo IATF (n=107)

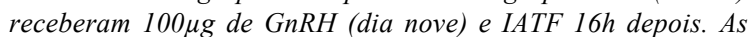
taxas de prenhez foram de 57,6\% (BioRep) e de 52,3\% (IATF). $O$ intervalo de 24 entre a retirada de MAP, mantido por oito dias, e a aplicação de GnRH não interfere na dinâmica folicular e na prenhez, permitindo inseminar vacas de corte amamentando sem observação de estro.

Palavras-chave: vacas de corte, pós-parto, IATF, MAP, ovulação.

\section{INTRODUCTION}

The synchronization and induction of estrus are interesting alternatives in production systems of suckled beef cows, since they enable most of the herd to return to cyclicity and begin a new gestation in a reduced period of time. Hormonal

'Laboratório de Biotecnologia e Reprodução Animal (BioRep), Departamento de Clínica de Grandes Animais, Universidade Federal de Santa Maria (UFSM), 97105-900, Santa Maria, RS, Brasil. E-mail: bayard@biorep.ufsm.br. *Autor para correspondência 
programs which eliminate the need for estrous detection and allow timed artificial insemination (TAI) are more attractive; however, they have pregnancy rates between 25 and 67\% (STEVENSON et al., 2000; BARUSELLI et al., 2004).

Our laboratory has developed a protocol named BioRep (SIQUEIRA et al., 2008) for postpartum cows which combines a short period of insemination with observation of estrus (48h) and TAI. This protocol uses a medroxyprogesterone acetate (MPA) device (MORAES \& JAUME, 1997) for seven days, treatment with estradiol benzoate (EB) and application of equine chorionic gonadotropin (eCG) and prostaglandin $\mathrm{F}_{2 \text { alpha }}$ analog on the sixth day, combined with a temporary interruption of suckling for $88 \mathrm{~h}$. This system gives average pregnancy results of $65 \%$ with a range of 50 to $80 \%$, based on the use of approximately 3000 animals (unpublished data). In the BioRep protocol, the eCG injection is performed one day before device removal while most of other protocols perform the injection at the time of device removal. The increase of one day after eCG application allows a larger follicular diameter at the moment of GnRH injection and therefore a high ovulation rate in response to LH surge (SARTORI et al., 2001). Using BioRep protocol, approximately a half of the bovine females were detected to be in estrus in the $48 \mathrm{~h}$ after the removal of the vaginal device (BASTOS et al., 2004; LOGUÉRCIO et al., 2005; SIQUEIRA et al., 2008). However, despite of good results, this system has limitations such as the interruption of suckling and, mainly, the need for estrous detection, which it has been indicated as the limiting factor in the success of artificial insemination in bovine. In an attempt to eliminate the observation of estrus, Siqueira et al. (2008) used EB 24h after the removal of MPA to induce ovulation maintaining the vaginal device for 7 days. However, the pregnancy rate was significantly lower when compared with the BioRep system.

Treatments with progestagen are effective in suppressing estrous manifestation and ovulation (YAVAS \& WALTON, 2000). Seven to nine days of progestagen treatments apparently do not affect neither the dominant follicular growth nor the synchronization of ovulation (UTT et al., 2003; CAVALIERI et al., 2004; CAVALIERI et al., 2007). Therefore, it was hypothesized that an increase on progestagen exposure period from seven to eight days decreases the interval between the device removal and application of $\mathrm{GnRH}$ with no affect on follicular growth rate. Thus, the aim of this study was to verify if a reduction in the interval between the MPA removal and the GnRH treatment from 48 to $24 \mathrm{~h}$ would affect the dominant follicle growth and pregnancy rates.

\section{MATERIALS AND METHODS}

Animals and experimental design

The experiments were carried out on a farm in the south of Brazil, at $30^{\circ} 10^{\prime} \mathrm{S}$ and $56^{\circ} 29^{\prime} \mathrm{W}$, using Hereford $(n=162)$ and crossbred Hereford $x$ Nelore $(n=65)$ lactating beef cows, ranging from 60 to 80 days postpartum with a body condition score of 3 (1extremely thin and 5 extremely fat). At the beginning of the treatment (day 0), the cows received an im injection of $5 \mathrm{mg}$ of $\mathrm{EB}$ and a progestin intravaginal device containing $250 \mathrm{mg}$ of MAP. On day 6 , all cows received an intravulvar injection of $125 \mu \mathrm{g}$ of cloprostenol $\left(\mathrm{PGF}_{2 \text { alpha }}\right.$ Sincrocio $^{\circledR}$, Ourofino, Brazil; GIOSO et al., 2005), 400UI of equine chorionic gonadotropin im (eCG; Prógon ${ }^{\circledR}$, Diprost, Uruguay) and the calves were weaned for 4 days. After, the animals were uniformly assigned into two groups and the intravaginal devices were removed on day 7 ( $24 \mathrm{~h}$ after eCG; BioRep Group) or day 8 (48h after the treatment with eCG; TAI Group). On day 9 ( $72 \mathrm{~h}$ after the treatment with eCG), $100 \mu \mathrm{g}$ of gonadorelin im $\left(\mathrm{GnRH}\right.$, Profertil $^{\circledR}$, Tortuga, Brazil) was administered to all of the animals (Figure 1).

\section{Experiment I}

The follicular growth of 14 Hereford cows (each group $=7$ ) were evaluated by transrectal ultrasound (Pie-Medical Scanner $200^{\circledR}$, linear array of $7.5 \mathrm{MHz}$ ). Every $24 \mathrm{~h}$, from day 6 (after eCG) to 9, the diameter and location of all ovarian follicles $\geq 5 \mathrm{~mm}$ were monitored and mapped. In order to determine the ovulation, two ultrasonographic evaluations were carried out, 24 and $36 \mathrm{~h}$ after of GnRH injection (day 9). Ovulation was defined as the disappearance of a follicle identified as a dominant follicle during the preceding examination.

\section{Experiment II}

One hundred forty-eight Hereford cows and 65 crossbred Hereford x Nelore cows were distributed proportionally into two experimental groups. In the animals of the BioRep Group $(n=106)$, the vaginal devices were removed on day 7 and the cows were observed, through visual observation, twice a day during 1 hour for estrous detection, for $48 \mathrm{~h}$, and inseminated $12 \mathrm{~h}$ after their detection. The animals which did not manifest estrus received $100 \mu \mathrm{g}$ im of GnRH (day 9) and were TAI 16h latter. In the TAI Group $(n=107)$, the vaginal devices were removed on day 8 , $100 \mu \mathrm{g}$ im of GnRH (day 9) were administered and TAI were carried out $16 \mathrm{~h}$ latter. Ultrasonographic pregnancy diagnosis was performed 35 days after AI. 


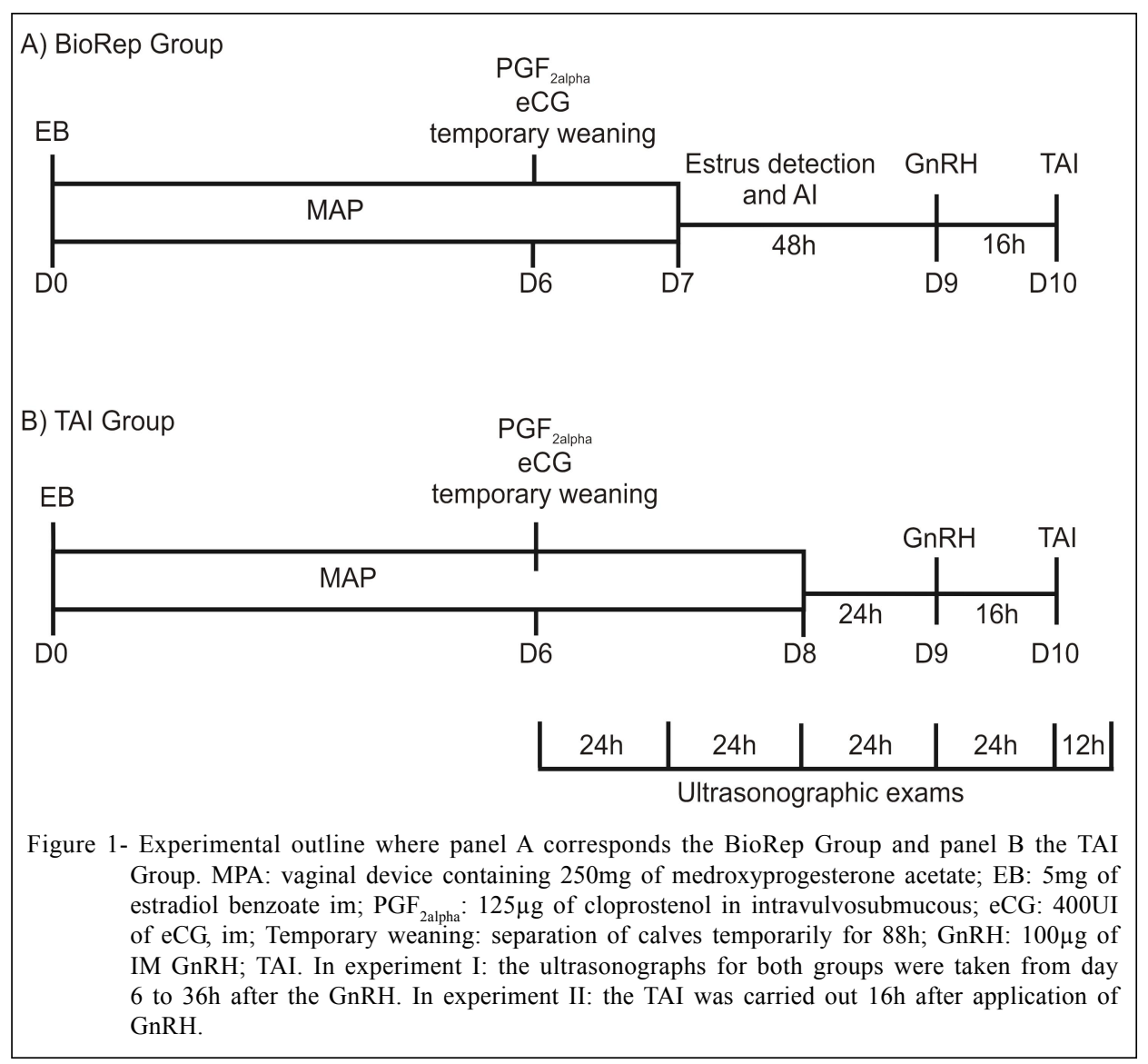

Statistical Analysis

In experiment 1, the follicular diameter was compared using mixed models analysis with a repeated statement (PROC MIXED; SAS). The main effects of group and day and their interaction were determined. Differences between follicular diameters on a specific day were compared between groups by estimate statement. In experiment II, the pregnancy rate was analyzed through the non parametric test using the PROC CATMOD in SAS software.

\section{RESULTS}

\section{Experiment I}

This experiment was designed to determine whether the maintenance of progestagen for 8 days would affect the follicular growth and ovulation in response to GnRH in beef cows during the postpartum, in a program which uses $\mathrm{eCG}$ and interrupted suckling. The average follicular diameters, on the days evaluated (6, 7,8 and 9), in the cows of BioRep Group $(6.4 \pm 0.93 \mathrm{~mm}$; $7.7 \pm 0.81 \mathrm{~mm} ; 9.7 \pm 0.97 \mathrm{~mm}$ and $11.1 \pm 0.99 \mathrm{~mm}$ ) and of TAI
Group $(6.3 \pm 0.83 \mathrm{~mm} ; 7.6 \pm 0.88 \mathrm{~mm} ; 9.5 \pm 0.80 \mathrm{~mm}$ and $11.5 \pm 0.65 \mathrm{~mm}$ ) did not differ. Also, it was observed daily effect on follicular growth in both groups after eCG treatment $(\mathrm{P}<0.001$; Figure 2$)$, however, there was no interaction between group and day $(\mathrm{P}>0.05)$ showing that the follicular growth profile was similar in both groups. All animals ovulated, however 2 out of 7 animals of the BioRep Group ovulated before the application GnRH injection, whereas 5 out of 7 animals of the BioRep Group and 3 out of 7 of the TAI Group ovulated within $24 \mathrm{~h}$ after the GnRH injection. The remainder animals of TAI group (4/7) ovulated between 24 and $36 \mathrm{~h}$ after application of $\mathrm{GnRH}$.

\section{Experiment II}

Since the follicular growth was similar for the BioRep and TAI Groups in experiment I, the second experiment was designed to evaluate the use of TAI, reducing from $48 \mathrm{~h}$ to $24 \mathrm{~h}$ the interval between progestin intravaginal device removal and GnRH injection. The BioRep Group showed an estrous distribution for $12 \mathrm{~h}$, $24 \mathrm{~h}, 36 \mathrm{~h}$ and $48 \mathrm{~h}$ after vaginal device removal of $8.5 \%$, 


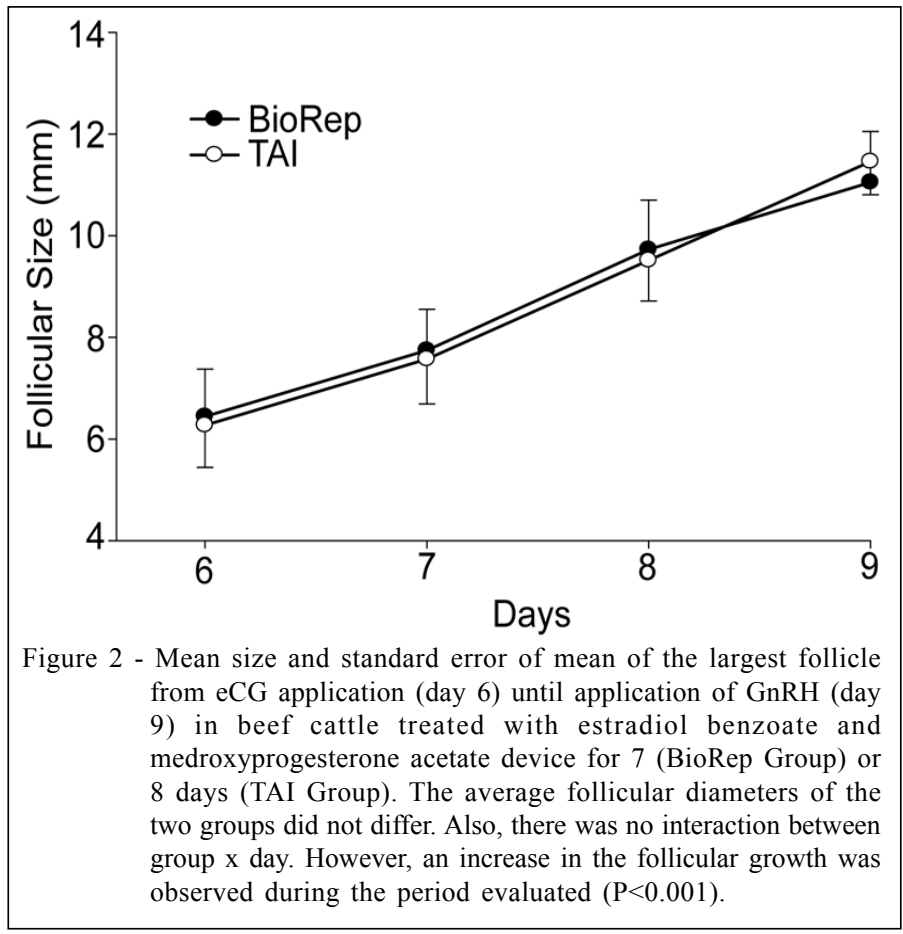

progestagen and estradiol benzoate at the beginning of the treatment inhibits the follicle growth regardless of the follicular size (SIQUEIRA et al., 2006) and synchronizes the emergence of a new wave between 4 and 5 days after protocol onset (BÓ et al., 1995). In this study, ultrasonographic evaluations were carried out after the $\mathrm{d} 6$ of treatment (eCG and interrupted suckling), to identify the dominant follicle and to follow its growth until the ovulation. The results given in figure 2 show the synchronized emergence of a follicular wave with similar follicular growth in the two groups demonstrating that the proposed approach does not alter the follicular dynamics.

The proposed system, with eCG and temporary interruption of suckling, provides conditions for follicular growth and its use has been shown to be effective in herds with low cyclicity rate, adverse body condition and during early postpartum period (BARUSELLI et al., 2003; PEÑA et al., 2005). The action of device for an eightday period maintains the subluteal plasma progesterone levels and inhibits the estrus and ovulation, acting on the hypothalamus and regulating the release of $\mathrm{GnRH}$ (PETERS et al., 1994; MIHM \& AUSTIN, 2002) and, consequently, the LH (KINDER et al., 1996). To carry out the TAI, it is necessary to know the expected time of ovulation. The use of ovulation inducers after the period of exposure to progestagens has been widely studied (BARUSELLI et al., 2004; BASTOS et al., 2004; SIQUEIRA et al., 2008). Currently, EB and the GnRH agonists are the most used, leading to varied pregnancy results. The administration of GnRH induces an $\mathrm{LH}$ surge which begins immediately after its application (LUCY \& STEVENSON, 1986), inducing ovulation in the preovulatory follicles with suitable concentrations of LH receptors. The concentration of LH receptors on granulosa cells increases during final follicular growth and the capacity of follicle to ovulate in response to

hypothesis that progestagen for an eight-day period combined with a reduction of the interval between the device removal and the GnRH injection reduces the estrous behavior before TAI, leading to an improved synchrony of the ovulation time, allowing a TAI with reasonable pregnancy rate. The combination of

Table 1 - Conception and pregnancy rates in cows 60-80 days postpartum, synchronized with medroxyprogesterone acetate (MPA) for 7 (BioRep group) or 8 days (TAI group).

\begin{tabular}{|c|c|c|c|c|}
\hline Group & $\begin{array}{c}\text { Cows } \\
n\end{array}$ & $\begin{array}{c}\text { Conception rate } \\
(\%)\end{array}$ & $\begin{array}{c}\text { TAI Pregnancy }{ }^{2} \\
(\%)\end{array}$ & $\begin{array}{c}\text { Final Pregnancy } \\
\qquad(\%)\end{array}$ \\
\hline BioRep & 106 & $39 / 54(72.2)$ & $22 / 52(42.3)$ & $61 / 106(57.6)$ \\
\hline TAI & 107 & - & $56 / 107(52.3)$ & $56 / 107(52.3)$ \\
\hline
\end{tabular}

\footnotetext{
1 - The number of cows diagnosed pregnant divided by the total number of cows inseminated after standing heat

2 -The number of cows diagnosed pregnant divided by the total number of cows inseminated without estrous detection.

3 - Total of pregnant cows divided by total number of cows in each group.
} 
LH surge is related with follicular diameter (SARTORI et al., 2001). The results for postpartum beef cows vary and, generally, low conception rates (STEVENSON et al., 2000; FERNANDES et al., 2001), have been associated with inadequate size of the dominant follicle at the time of ovulation induction (BURKE et al., 2001). Both protocols used in this study lead to preovulatory follicles responsive to GnRH (Figure 2), resulting in ovulation within $36 \mathrm{~h}$ after injection.

The eCG acts as a follicle stimulating hormone (FSH) and to a lesser extent a luteinizing hormone (LH), and has a positive effect when used to stimulate the follicular growth in postpartum (MURPHY \& MARTINUK, 1991). BÓ et al. (2006) maintained progesterone devices for seven and a half days or eight days, observed a better ovulation synchrony when the GnRH was administered 24h after device remove compared to administration at 36 or $48 \mathrm{~h}$. However, AMBROSE et al. (2005) and COLAZO et al. (2008) recommend the application of GnRH between 36-48h hours after the removal of the vaginal device with progestagen, in order to obtain high ovulation rate. In this study, estrous behavior rate was $50.9 \%$ in the $48 \mathrm{~h}$ period between device removal and application of $\mathrm{GnRH}$, similar to previous studies using the BioRep protocol (BASTOS et al., 2004; LOGUÉRCIO et al., 2005; SIQUEIRA et al., 2008).

Artificial insemination after estrous detection usually results in a conception rate of 50 to $90 \%$. This range is normally correlated with early embryonic losses in the first 30 days after insemination (HUMBLOT et al., 2001; SANTOS et al., 2004). However, other factors may influence the conception rate, such as the semen quality, inseminator ability, body condition and cow fertility (YAVAS \& WALTON, 2000). The pregnancy rate observed in this study are close to the average $(50 \%)$ found in the literature in postpartum cows after the estrous induction protocols (MACIEL et al., 2001; BARUSELLI et al., 2004; BASTOS et al., 2004; LOGUÉRCIO et al., 2005; SIQUEIRA et al., 2008). Thus, the $24 \mathrm{~h}$ interval between the MPA removal on day 8 and GnRH administration, with eCG and temporary weaning on the day six, allows an efficient TAI system for use in beef cows $60-80$ days post partum without detection.

\section{ACKNOWLEDGEMENTS}

We are grateful to Conselho Nacional de Desenvolvimento Científico e Tecnológico (CNPq) and Coordenação de Aperfeiçoamento de Pessoal de Nível Superior (CAPES) for the financial support and to Estância do Angico for providing the animal facilities.

\section{REFERENCES}

AMBROSE, J.D. et al. Progesterone (CIDR)-based timed AI protocols using $\mathrm{GnRH}$, porcine LH or estradiol cypionate for dairy heifers: ovarian and endocrine responses and pregnancy rates. Theriogenology, v.53, p.1121-1134, 2005.

BARUSELLI, P.S. et al. Effect of eCG on pregnancy rates of lactating zebu beef cows treated with CIDR-B devices for time artificial insemination. Theriogenology, v.59, p.214, 2003.

BARUSELLI, P.S. et al. The use of hormonal treatments to improve reproductive performance of anestrous beef cattle in tropical climates. Animal Reproduction Science, v.82, p.479-486, 2004.

BASTOS, G.M. et al. Hormonal induction of ovulation and artificial insemination in suckled beef cows under nutritional stress. Theriogenology, v.62, p.847-853, 2004.

BÓ, G.A. et al. Exogenous control of follicular wave emergency in cattle. Theriogenology, v.43, p.31-40, 1995.

BÓ, G.A. et al. The timing of ovulation and insemination schedules in superstimulated cattle. Theriogenology, v.65, p. $89-111,2006$.

BURKE, C.R. et al. Effects of maturity of the potential ovulatory follicle on induction of oestrus and ovulation in cattle with oestradiol benzoate. Animal Reproduction Science, v.66, p.161-174, 2001.

CAVALIERI, J. et al. Ovarian follicular development in Holstein cows following synchronization of oestrus with oestradiol benzoate and an intravaginal progesterone releasing insert for 5-9 days and duration of the oestrus cycle and concentrations of progesterone following ovulation. Animal Reproduction Science, v.81, p.177-193, 2004.

CAVALIERI, J. et al. Reproductive performance of lactating dairy cows and heifers resynchronized for a second insemination with an intravaginal progesterone-releasing device for 7 or $8 \mathrm{~d}$ with estradiol benzoate injected at the time of device insertion and $24 \mathrm{~h}$ after removal. Theriogenology, v.67, p.824-834, 2007.

COLAZO, M.G. et al. Effects of plasma progesterone concentrations on LH release and ovulation in beef cattle given GnRH. Domestic Animal Endocrinology, v.34, p.109-117, 2008.

EVANS, A.C.O.; FORTUNE, J.E. Selection of the dominant follicle occurs in the absence of the differences in the expression of messenger ribonucleic acid for gonadotropin receptors. Endocrinology, v.138, p.2963-2971, 1997.

FERNANDES, P. et al. Timed artificial insemination in beef cattle using GnRH agonist PGF2alpha and estradiol benzoate. Theriogenology, v.55, p.1521-1532, 2001.

GIOSO et al. Angioarquitetura venosa do órgão genital da fêmea bovina. Arquivo Brasileiro de Medicina Veterinária e Zootecnia, v.57, n.6, p.715-719, 2005. 
HUMBLOT, P. et al. Use of pregnancy specific proteins and progesterone assays to monitor pregnancy and determine the timing, frequencies and sources of embryonic mortality in ruminants. Theriogenology, v.56, p.1417-1433, 2001.

KINDER, J.E. et al. Progestin and estrogen regulation of pulsatile LH release and development of persistent ovarian follicles in cattle. Journal of Animal Science, v.74, p.14241440, 1996

LOGUÉRCIO, R.S. Regulação de receptores esteróides e dinâmica folicular em um sistema de indução hormonal pós-parto em vacas de corte. 2005. 80f. Tese (Doutorado em Medicina Veterinária) - Curso de Pós-graduação em Medicina Veterinária, Universidade Federal de Santa Maria, Santa Maria, RS.

LUCY, M.C.; STEVENSON, J.S. Gonadotropin-releasing hormone at estrus: luteinizing hormone, estradiol, and progesterone during the periestrual and postinsemination periods in dairy cattle. Biology of Reproduction, v.35, p.300$311,1986$.

MACIEL, M.N. et al. Programa hormonal associado ao desmame temporário na indução de ovulação em vacas de corte durante o pós-parto. Ciência Rural, v.31, n.3, p.473-478, 2001 .

MIHM, M.; AUSTIN, E.J. The final stages of dominant follicle selection in cattle. Domestical Animal Endocrinology, v.23, p.155-166, 2002 .

MORAES, J.C.F.; JAUME, C.M. Sincrobovi: um pessário para sincronização de cios em bovinos. Revista Brasileira de Reprodução Animal, v.21, n.2, p.99-101, 1997.

MURPHY, B.D.; MARTINUK, S.D. Equine chorionic gonadotropin. Endocrine Reviews, v.12, p.27-44, 1991.

PEÑA, D.M. et al. Efecto de la aplicación de eCG y destete temporario sobre los porcentajes de preñez em vacas posparto tratadas com DIB y benzoato de estradiol In: SIMPOSIO INTERNACIONAL DE REPRDUCIÓN ANIMAL, 6., 2005, Cordoba, CO. Anais... Córdoba: IRAC, 2005. V.6. 515p. p.408.

PETERS, K.E. et al. Luteinizing hormone has a role in development of fully functional corpora lutea (CL) but is not required to maintain $\mathrm{CL}$ function in heifers. Biology of Reproduction, v.51, n.6, p.1248-1254, 1994.

SANTOS, J.E.P. et al. The effect of embryonic death rates in cattle on the efficacy of estrus synchronization programs. Animal Reproduction Science, v.82-83, p.513-535, 2004.

SARTORI, R. et al. Follicular deviation and acquisition of ovulatory capacity in bovine follicles. Biology of Reproduction, v.65, p.1403-1409, 2001.

SIQUEIRA, L.C. et al. Progestágenos associados à estrógenos são capazes de induzir atresia de folículos com baixa dependência de gonadotrofinas? In: REUNIÃOANUAL DA SOCIEDADE BRASILEIRA DE TECNOLOGIA DE EMBRIÕES, 20., 2006, Araxá, MG. Anais... Araxá: SBTE, 2006. V.34. 597p. p.361.

SIQUEIRA, L.C. et al. Sistemas de inseminação artificial em dois dias ou em tempo fixo para vacas amamentando. Ciência Rural, v.38, n.2, p.411-415, 2008.

STEVENSON, J.S. et al. Synchronizing estrus and (or) ovulation in beef cows after combination of GnRH, norgestomet, and prostaglandin F2 alpha with or without timed insemination. Journal of Animal Science, v.78, p.1747-1758, 2000.

UTT, M.D. et al. The effect of varying the interval from follicular wave emergence to progestin withdrawal on follicular dynamics and the synchrony of estrus in beef cattle. Journal Animal Science, v.81, p.1562-1567, 2003.

YAVAS, Y.; WALTON, J.S. Postpartum acyclicity in suckled beef cows: a review. Theriogenology, v.54, p.25-55, 2000. 